\title{
O USO DO MATERIAL GENÉTICO DESCARTADO COMO VIOLAÇÃO AO FAIR PLAY NO PROCESSO PENAL.
}

\section{THE USE OF DISPOSED GENETIC MATERIAL AS A VIOLATION OF THE FAIR PLAY IN CRIMINAL PROCEDURE.}

\author{
Irene Portella ${ }^{1}$ \\ Fábio André Guaragni ${ }^{2}$ \\ Guilherme Ramos Justus ${ }^{3}$
}

\begin{abstract}
Resumo
O direito a não autoincriminação é um preceito muito caro do processo penal constitucional. Porém, casos em que tal garantia individual entra em conflito com interesses de cunho público têm desnivelado o jogo processual em favor do órgão acusador. $\mathrm{O}$ entendimento de que material genético extraído de forma não invasiva, de um tecido descartado, mesmo com a expressa negativa do titular renova o debate a respeito da real característica do sistema penal. Considerar como lícita a prova colhida nesses termos é uma mácula ao fair play processual, ou seja, uma fraude no resultado do jogo. Assim, com o objetivo do artigo é demonstrar como a equivocada sobreposição de princípios relacionados ao processo pode acarretar em uma decisão previsível dopada.
\end{abstract}

Palavras-chave: Teoria dos jogos, processo penal, garantias individuais.

\begin{abstract}
The right to non-self-incrimination is a very important precept of constitutional criminal proceedings. However, cases in which such individual guarantee conflicts with public interest, reveals an unevenly advantage for the prosecution. The understanding that non-invasively extracted genetic material from discarded tissue, even with the expressive negative of the holder, renews the debate about the real feature of the criminal law system. Considering lawful the evidence gathered in these terms is a fraud to procedural fair play, is a fraud in the outcome of the procedural game. Thus, the aim of the paper is to demonstrate how the misguided overlap of principles related to the process can lead to a predictable decision.
\end{abstract}

\footnotetext{
${ }^{1}$ Doutora em Direito Constitucional pelo departamento de Direito Público e Teoria do Estado, pela Universidade de Santiago de Compostela.

${ }^{2}$ Procurador de Justiça no Estado do Paraná, Doutor e Mestre em Direito das Relações Sociais (UFPR). Professor de Direito Penal Econômico do Programa de Mestrado em Direito Empresarial e Cidadania do Centro Universitário Curitiba. Professor de Direito Penal do Unicuritiba, Fempar, Esmae, Cejur e LFG.

${ }^{3}$ Bacharel em Direito pelo Centro Universitário Curitiba, Especialista em Direito Penal e Processual Penal pelo Centro de Estudos Prof. Luiz Carlos, Especialista em Direito Aplicado pela Escola da Magistratura do Paraná, Mestrando em Direito Empresarial e Cidadania pelo Centro Universitário Curitiba.
} 
Keywords: Game theory, criminal procedure, individual guarantees.

\section{INTRODUÇÃO}

Para que seja possível que uma decisão judicial limite direitos a um cidadão é necessário que a fundamentação para tal esteja constituída em provas significativas e que superem a dúvida razoável. Ocorre que em múltiplas hipóteses a perquirição da verdade dos fatos impõe que as provas atentem contra a disponibilidade física e de intimidade do indivíduo, o que geram consideráveis discussões quanto a sua legalidade.

Evidentemente, o primeiro filtro principiológico cogitado é o direito a não produzir prova contra si mesmo, o qual desobriga o indivíduo a dispor de qualquer parte de seu corpo para servir de prova para uma eventual condenação criminal. Tal panorama é próprio de um sistema acusatório, cujo princípio norteador é a presunção de inocência. Porém, infelizmente, o jogo processual penal parece não estar se encaixando na estrutura punitivista atual, onde o suposto interesse coletivo prepondera sobre as garantias individuais, em especial quanto ao princípio da não autoincriminação e o direito à intimidade.

A discussão proposta objetiva analisar a utilização de material genético proveniente de tecidos disponíveis do corpo humano, retirados de forma não invasiva e sem a concordância da parte como meio de prova no jogo processual. Ou seja, visa demonstrar, através da teoria dos jogos aplicada ao processo penal, como uma equivocada análise de princípios pode violar frontalmente garantias individuais e macular o jogo processual penal. Além da perigosa aplicação da teoria da ponderação de princípios, fundamental é a reflexão quanto à superação da ideia de que o processo penal e o processo civil ainda compartilham uma teoria geral capaz de dirimir eventuais incompatibilidades.

A reflexão no tocante ao direito à prova é profunda e necessária, pois extrapola as discussões travadas nos tribunais a respeito apenas do grau de intervenção dos procedimentos de coleta. O constante desenvolvimento tecnológico amplia consideravelmente o rol de materiais passíveis de análise de perfil genético, ou 
seja, mesmo que não queira e sem perceber, o acusado pode contribuir com material genético para seu eventual prejuízo.

\section{A TEORIA DOS JOGOS COMO FUNDAMENTO PARA ANÁlISE DO DIREITO A PROVA}

Primeiramente, para que a reflexão sobre o tema proposto seja adequada, fundamental é uma breve introdução a respeito da teoria dos jogos. Tomando como base os fundamentos de Johan Huzinga (2008), tem-se que a noção de jogo é antiga, pois seria através de um jogo que a civilização surge e se desenvolve. Segundo Huzinga, todo jogo significa alguma coisa no sistema da vida, sejam descargas de adrenalina, estados emocionais, tensão, estratégias, táticas e etc. Importante pontuar que o jogo em si não se trata de "jogos de azar", os quais ficam quase que integralmente no campo da probabilidade e do acaso, mas sim de uma multiplicidade de fatores, os quais podem ser controlados até certo ponto.

Atribuindo tal visão filosófica ao direito, Gregorio Robles (2010) entende que o direito pode ser comparado ao jogo, uma vez que em ambos os campos são necessários comportamentos de competência, cooperação, conflito e luta, sendo que o pretenso resultado não repousa somente no acaso ou na sorte de um dos jogadores, mais também na performance de cada um em fase do árbitro da partida, o qual seria o Estado Juiz.

Seguindo a linha de pensamento destes autores, notória é a obra de Alexandre Morais da Rosa quanto à aplicabilidade da teoria dos jogos no processo judicial brasileiro. Desenvolvendo tais ideias, o autor brasileiro destaca reflexões de Piero Calamandrei, no sentido de que há uma multiplicidade de fatores para se analisar no andamento do jogo processual, principalmente ao utilizar-se da analogia feita com os jogos de tabuleiros, pois decorar as regras do xadrez não torna o sujeito um grande enxadrista. Da mesma forma, saber as regras do processo não capacita a parte como um grande jogador processual. Por outro lado, o desconhecimento das regras limita a atuação do jogador ou julgador (ROSA, 2014). Assim, as regras do jogo processual são impostas pelo Estado, as quais são sustentadas por um árbitro, no caso, o magistrado. Os tempos dos jogos seriam compreendidos como a denúncia, no caso do 
processo penal, até o trânsito em julgado da sentença. Por óbvio, entende-se como o espaço do jogo, ou o estádio, o tribunal. ${ }^{4}$

De forma bem objetiva, Alexandre Morais da Rosa estabelece três planos paralelos e simultâneos do jogo processual, são eles: a) o reconhecimento da existência das normas processuais, no caso, os princípios e regras, os quais são lançados processualmente pelas partes e pelo juiz; b) a teoria da informação probatória e seus respectivos fatores de convencimento, em outras palavras, os condicionantes internos e externos que influenciam, nas jogadas e, por fim, c) a singularidade do processo, uma vez que há julgador e jogadores, táticas e estratégias distintas. Assim, ao mesmo tempo em que se aplicam estruturas padronizadas e, em tese, universais, não se pode desconsiderar o importante fator da singularidade de cada demanda. Em síntese, mesmo que se apliquem regras gerais, o fato de existirem jogadores, julgadores e fatos distintos, o resultado nunca será o mesmo. Nas palavras do magistrado catarinense, cada decisão de jogo processual é artesanal.

Para entender melhor a lógica e a dinâmica do jogo processual, também é necessário entender que o processo se assemelha a uma guerra autorizada pelo Estado, sendo que nem sempre o mais forte sairá vencedor. A dinâmica do jogo processual entendida pela metáfora da guerra sustenta como algo em desequilíbrio, pois o julgador e os jogadores tomam decisões maximizadoras de seus interesses a partir de uma análise de prós e contras, denominados como payoffs e não levam e consideração as consequências e prejuízos individuais à coletividade.

De forma mais sintética, o processo penal seria um jogo mediado pelo estado juiz em que a fortaleza do estado de inocência é atacada pelo jogador acusador $(\mathrm{O}$ Ministério Público no caso das Ações Penais Públicas) e defendida pelo jogador defensor (Defesa). O jogador acusador tem como objetivo romper com a fortaleza da inocência, enquanto o jogador de defesa busca sustentar tal posição. Assim, sucedemse estratégias e táticas processuais para os efeitos pretendidos, no caso, a aplicação ou não de uma pena.

\footnotetext{
4 "De alguma maneira o jogo processual penal dá ordem parcial ao caos, estipulando o local de jogo, seus limites, regra, jogadores e julgadores. Daí seu efeito cativante. Para ser um bom jogador não basta somente conhecer as regras processuais. É preciso ter habilidade, inteligência, ritmo, harmonia, capacidade de improviso e fair play. Ao se assumir a função de jogador ou julgador, no jogo processual penal, acontece a criação de ambiente apartado das preferências pessoais. Utilizam-se máscaras e lugares diferenciados, para os quais a estética, a performance, roubam a cena. O espetáculo do jogo processual lança luzes narcísicas, promove o aparecimento de trações não existentes e/ou obliterados na vida privada. Pulsa. Agita. Explode. É o rito coletivo pelo qual a punição se legitima”. Ibid.
} 
Assim, considerando tal lógica de jogo, óbvia é a constatação de que o período de maior intensidade de táticas e estratégias se dá no momento da produção probatória, uma vez que é o momento em se constituem as provas significativas para sustentar a decisão do julgador. Dentro dessa intensa produção probatória é que se verifica o regime de sua respectiva obtenção, sendo lícitas ou ilícitas, reguladas através de uma ideia de input/output de informações que poderão ser consideradas e valoradas pelo Estado para firmar (ou afastar) a responsabilização penal de investigados e acusados (ROSA, 2017, p. 700).

Ainda, podemos ter um standard probatório do tipo hard ou flex, o qual pode ser definido pelo grau de exigência de input (ou inclusão) e pela possibilidade do output (exclusão) das informações produzidas em desacordo com as regras processuais convencionais. Por essa razão é que a atitude do órgão julgador no que diz respeito às regras processuais será a informação relevante para que estabeleçam as táticas dominantes (ROSA, 2017, p.701). Aqui a discussão ganha novos ares, pois fundamental é o debate sobre o a noção do standard probatório, uma vez que a autonomia do direito processual penal estabelece condições mínimas e, muitas vezes, não suficientes para a afirmação dos fatos, em tese, provados e capazes de atribuir a responsabilidade em razão de um delito. Em suma, provar é proporcionar ao ente julgador que informações aptas a qualificar a situação como confirmada ou não ${ }^{5}$.

Dentro dessa dinâmica probatória, destaca-se a posição ocupada pelo acusado, ao qual é resguardado o direito de não produzir prova que lhe prejudique, ou que possa lhe prejudicar (nemo tenetur se detegere). Em síntese, a ideia da não autoincriminação ${ }^{6}$ implica em uma defesa pessoal negativa, uma vez que não está obrigado a se submeter a procedimentos de reconstituição, acareação, reconhecimento, exames periciais, extração de DNA, fornecimento de materiais gráficos e vocais, entre outros (ROSA, 2017, p. 715). Apesar de legítima, a recusa

\footnotetext{
5 "Provar no processo é demonstrar ao julgador, dar-lhe a conhecer a existência de um determinado fato (que), num espaço (onde) e tempo (quando) razoáveis. Também é proceder à verificação dos impulsos criadores do fato (porque) e as circunstâncias deste (como), para que possa ser emitido um juízo acerca das situações processuais que se desenvolvem nos autos, bem como acerca da responsabilidade criminal do acusado." GIACOMOLLI, Nereu José. Valor da prova no âmbito da cooperação jurídica internacional em matéria criminal. In PRADO, Geraldo; GIACOMOLLI, Nereu José et al (orgs). Prova Penal: Estado Democrático de Direito. Florianópolis: Empório do Direito, 2015. p. 39.

6 "A carga da prova da existência de todos os elementos positivos e a ausência dos elementos negativos do delito incumbe a quem acusa. Por isso, o sujeito passivo não pode ser compelido a auxiliar a acusação a liberar-se de uma carga que não lhe incumbe.” (LOPES JR., 2018, p. 434.)
} 
resulta em um efeito negativo ao ente julgador em razão da dissonância cognitiva, pois ainda que oculto, permanece vigente o dito popular do "quem deve não teme".

Diante de tais circunstâncias do jogo processual é que justifica o debate a respeito da atuação (positiva ou negativa) do acusado no standard probatório, em especial quanto ao seu direito de não fornecer material genético, ainda que descartado, para a produção da prova.

\section{O MATERIAL GENÉtico COMO MEIO DE PROVA NO PROCESSO PENAL}

A evolução da pesquisa científica propicia uma série avanços tecnológicos que influenciam todo o modo de vida da sociedade. Ocorre que tais reflexos da modernidade também afetam as relações jurídicas contemporâneas. $\mathrm{O}$ exemplo mais próximo, bem como o mais propício a maiores debates, é o exame de DNA, o qual é a forma mais elaborada para identificar o perfil genético de uma pessoa.

Por consequência, tendo uma precisão absolutamente alta, o exame de perfil genético passa a ser um meio de prova extremamente eficaz e cada vez mais acessível. Adicione-se ao fato de que cada vez mais o exame passa a ser menos invasivo, pois não são mais necessárias amostras sanguíneas para que seja possível fazer a identificação genética do individuo. Ocorre que esta maior acessibilidade também possui um contraponto relevante para fins processuais, pois esse tipo de prova técnica poderia ser produzida sem a concordância do acusado, o que acarreta uma série de irregularidades.

Primeiramente, cabe a referência que não existem maiores discussões a respeito da obtenção de material genético encontrado no local do crime como produto de busca e apreensão domiciliar e pessoal, conforme a lógica dos artigos 240 e seguintes do Código de Processo Penal. Da mesma forma, havendo concordância do acusado em fornecer o material genético para a realização do exame pericial, não se vislumbram nulidades. Nesse sentido, entende-se que está ciente de que não possui a incumbência de produzir ou auxiliar a produção de prova que pode lhe prejudicar, o 


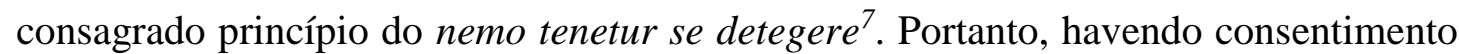
do investigado, poderá ser realizado o exame pericial após a intervenção corporal, uma vez que a autodefesa é um direito disponível (LOPES JR, 2018, p. 433).

A grande questão em debate diz respeito às situações em que são necessárias amostras genéticas do sujeito e este se recusa a fornecê-las. Se no âmbito civil o conflito poderá ser resolvido com a simples inversão da carga probatória, uma vez que haveria uma presunção de veracidade das questões não constadas ou impugnadas. De fato, a solução do processo civil é mais simples e objetiva, uma vez que se distribui o ônus da prova, e estabelecem-se regras destinadas a nortear a atividade do julgador, o que sistematiza o jogo processual civil. Nesse ponto, relevante é a distinção feita por Pontes de Miranda, no sentido de que há uma diferença substancial entre o dever e o ônus. Segundo o entendimento do renomado autor, o dever é em relação a alguém, mesmo que esse alguém seja a sociedade ou uma coletividade, pois há uma relação entre dois sujeitos, um dois quais é o que se deve, ou seja, a satisfação é do interesse do sujeito ativo da relação. Já o ônus é uma relação unilateral, ou seja, não há uma relação entre sujeitos, mas em si mesmo, assim, o interesse na satisfação é do próprio onerado. Em síntese, não há sujeição do onerado, ele escolhe entre satisfazer ou não ter a tutela do seu interesse. Assim, a teoria do ônus da prova diz respeito à pretensão, à tutela jurídica. O ônus da prova é, primordialmente, a ideia do prius evita o non liquet. De forma bem objetiva, aquele que tem interesse na afirmação é quem tem o ônus da prova, diz-se ônus, pois o provar é no interesse próprio, para que tal circunstância não caia no vácuo (MIRANDA, 2000, p. 457458). Desta forma, fornecem-se parâmetros para que as partes litigantes previamente estabeleçam estratégias probatórias de acordo com o polo que ocupam, os quais, em tese, não se enquadram em situações díspares ou de vulnerabilidade. Se está no polo ativo, compete-lhe provar apenas o fato constitutivo de seu direito pretendido com a demanda judicial. Já ao polo passivo cabe provas fato impeditivo, modificativo ou extintivo do direito alegado pelo autor (WAMBIER; TALAMINI, 2013, p. 507-508).

Porém, no processo penal a lógica não é a mesma, tal afirmação se justifica em razão do princípio da não autoincriminação e do direito ao silêncio, o qual não

\footnotetext{
7 "Situação complexa é o ranço histórico de tratar o imputado (seja ele réu ou mero suspeito, ainda na fase pré-processual) como um mero 'objeto' de provas, ou melhor, o 'objeto' do qual deve ser extraída a 'verdade' que funda o processo inquisitório. Com a superação dessa coisificação do réu e a assunção de seu status de sujeito de direito, funda-se o mais sagrado de todos os direitos: o direito de não produzir prova contra si mesmo (nada a temer por se deter - nemo tenetur se detegere)." (LOPES JR., 2018, p. 432-433).
} 
pode prejudicar o acusado, os quais estão positivados na Constituição da República (Art. 5 $5^{\circ}$, inciso LXIII) e na Convenção Americana de Direitos Humanos ${ }^{8}$. Ainda, pacífico é o entendimento em se tratando de um exame invasivo, no caso da retirada de sangue para a realização do exame de perfil genético, o investigado (ou acusado) não se obriga fornecer o material.

O ponto de maior polêmica é a realização de exame de DNA em material genético descartado pelo próprio acusado, do qual são passíveis de realização de exames de confrontos genéticos, como por exemplo unhas e fios de cabelo. Ou seja, sendo a amostra genética descartada, não seria necessária a intervenção do acusado, bem como não há necessidade de interferir na esfera corporal do individuo, pois o material foi recolhido de forma não invasiva. Pontue-se que na hipótese do fio de cabelo como material genético o descarte pode ocorrer de forma absolutamente imperceptível, uma vez que a queda diária de fios cabelo é algo absolutamente natural do ser humano.

Nesse sentido, por se tratar de uma prova não invasiva, segundo Castro (2007, p. 101), em tese, não há violação à integridade física e/ou intimidade, pois seriam fruto do descarte e não de uma contribuição efetiva (positiva). Destaque-se que tal entendimento é pacífico nos tribunais brasileiros, reforçando a ideia de que não há mácula aos direitos fundamentais do indivíduo, sendo apenas necessárias ponderações entre a razoabilidade e a proporcionalidade no caso concreto.

Fortalecendo a ideia de que são necessárias revisões de preceitos (ou “mantras") jurídicos aplicados ao processo penal, mais especificamente às provas técnicas, Aury Lopes Jr (2018, p. 439) constrói uma argumentação no sentido de o discurso científico é muito sedutor, pois seria uma situação equiparada ao dogma religioso, como se tivesse status de ambição de verdade. Assim, se teria construído uma (pseudo)verdade no tocante às provas científicas, com a pretensão de que são irrefutáveis. De fato, não há como se negar que o imenso valor do saber científico no campo probatório, porém, nas palavras do autor, não há uma "rainha" das provas no processo penal. Tal entendimento confirma a ideia de o exame de DNA não ostenta um status absoluto. Tanto é que muitas das vezes a paridade do perfil genético pode apenas atestar parte do nexo causal entre a ação e o resultado típico, por exemplo: não

\footnotetext{
8 "Art. 186. Depois de devidamente qualificado e cientificado do inteiro teor da acusação, o acusado será informado pelo juiz, antes de iniciar o interrogatório, do seu direito de permanecer calado e de não responder perguntas que lhe forem formuladas. Parágrafo único: $\mathrm{O}$ silêncio, que não importará em confissão, não poderá ser interpretado em prejuízo da defesa."
} 
é razoável que registro de material genérico de um indivíduo seja a única ligação entre uma vítima de crime sexual (LOPES, JR, 2018, p. 440). Relembre-se que a valoração das provas, bem como a decisão de mérito é atributo do magistrado competente e não do perito ${ }^{9}$, ou seja, o direito não passa ser uma ciência exata.

Além da questão da valoração de provas, legítimas ou não, os conflitos em envolvem esses impasses são julgados através da análise principiológica preponderante. Para ilustrar melhor as peculiaridades enfrentadas pelos tribunais, serão trabalhados dois casos midiáticos da justiça brasileira a seguir.

\section{CASOS PRÁTICOS DA JURISPRUDÊNCIA BRASILEIRA}

$\mathrm{Na}$ jurisprudência nacional, relevante é a referência à dois casos emblemáticos: o "Caso Gloria Trevi" e o "Caso Pedrinho", ambos levantavam a questão da utilização do material genético para a produção de prova.

O caso da cantora mexicana Glória Trevi ocorreu em 2002, quando esta foi detida para aguardar o julgamento do pedido de extradição para o seu país natal. No período em que ficou custodiada nas dependências da Polícia Federal do Distrito Federal, a cantora alegou ter sido vítima de vários estupros pelos carcereiros e agentes policiais, sendo que destas violências sexuais acabou engravidando. Frente a uma gravíssima imputação, os acusados de violência sexual solicitaram a realização de exame de DNA para provar que as acusações eram inverídicas. Porém, Glória Trevi impetrou a Reclamação n. 2.040-DF sob o argumento de que teria o direito à intimidade e a preservação da identidade do pai da criança violado, contrapondo-se à decisão proferida pelo juízo da $10^{\mathrm{a}}$ Vara da Seção Judiciária do Distrito Federal, a qual tinha autorizado a coleta do material genético da placenta da cantora mexicana. Curiosamente, consta do relatório das investigações policiais que o delegado que presidia o inquérito sugere, alternativamente, a coleta de fios de cabelo ou "swab" bucal (passagem de um cotonete na face interna da gengiva da criança, objetivando a coleta de células descamadas da mucosa oral).

Assim, o Supremo Tribunal Federal entendeu que havia um aparente conflito

\footnotetext{
${ }^{9}$ [...] quem julgará é o magistrado, não o perito. Se entendermos o contrário, estamos colocando a prestação jurisdicional nas mãos de um médico- perito, e não nas de um profissional formado em Direito e concursado para exercer tal função, como determina a Constituição da República. (CASTRO, 2007, p.114).
} 
entre o direito à intimidade, a honra dos agentes acusados e direito de imagem da instituição pública ${ }^{10}$. Quanto ao procedimento não invasivo realizado para a coleta do material genético da então gestante, relevante é a manifestação do Ministro Relator Néri da Silveira:

"Esses bens e valores, por sua quantidade significativa, atingidos, autorizam se adote solução realmente consistente para 0 esclarecimento da verdade, quanto à participação eventual dos servidores públicos em apreço no ato da alegada violência sexual aludido pela reclamante, a quem não caberá, agora, escudar-se na só invocação do direito à intimidade, para impedir se possam averiguar os fatos em sua plenitude, o que está a exigir efetivamente se confronte o DNA do filho da reclamante com o 'material biológico sangue periférico' (fls. 113) dos policiais federais e outras pessoas, no total de 61, inclusive as apontadas nominalmente, nas reportagens e depoimentos como principais suspeitos, esclarecendose, às fls. 113, que todos, objetivando o esclarecimento dos fatos, assim procederam, não demonstrando 'nenhum temor quanto ao resultado da perícia (fls. 113)'.".11

Em sentido diverso e vencido na votação, o Ministro Marco Aurélio apresentou a seguinte posição:

"Por último, mencionou-se - o que já foi rechaçado pelo ministro Celso de Melo - o fato de a placenta ser um lixo biológico. Eu diria que a placenta, realmente, é desprezada, mas, no caso, não cabe potencializar esse fato. É preciso perquirir se estará em jogo a intimidade da extraditanda, com a busca dessa placenta no lixo e com o exame. E a resposta, aqui, é positiva. Uma coisa é desprezála, outra coisa é dar-lhe uma utilidade que vulnere, agrida o bem protegido constitucionalmente: a intimidade da própria pessoa. ${ }^{12}$

\footnotetext{
10 "Em realidade, assim, de um lado, a extraditanda, ora reclamante, com base no art. 5', inciso X, da Constituição, alega como o faz na inicial seu direito fundamental à intimidade, à vida privada, em não concordando com qualquer exame de material genético dela e de seu filho (fls. 3), e, de outra parte, os Policiais Federais (fls. 186), atingidos, consoante alegam, em sua honra, pelas acusações da reclamante, juntamente com o Delegado Federal que preside o Inquérito Policial em que se apuram os fatos ligados à origem da gravidez da requerente, e o Ministério Público Federal, invocando, por igual, o direito à honra e à imagem, ut art. $5^{\circ}, \mathrm{X}$, da Constituição, sustentam a imprescindibilidade da prova do DNA do filho da reclamante, recém-nascido, o que se pode obter por meio da placenta retirada da reclamante. Põe-se, aqui, portanto, em confronto alegações de direitos fundamentais à intimidade, de um lado, e à honra e imagem de outro lado, previstos no art. $5^{\circ}$, inciso X, da Lei Magna da República." Supremo Tribunal Federal. Reclamação n. 2.040/DF, Relator: Ministro Néri da Silveira. Data de julgamento: 21/02/2002, Tribunal Pleno.

11 ibid.

12 ibid.
} 
Dessa forma, considerando que a maioria dos ministros acompanhou o voto do relator, foi concedida a autorização da realização do exame de DNA em uma amostra da placenta descartada após o procedimento do parto. A prova em questão não foi considerada invasiva, pois foi colhido o material a partir de um tecido humano descartado.

Quanto ao descarte de material humano e o direito de disposição de partes do corpo humano, relevante é a afirmação de Anderson Schreiber no sentido de que em casos similares ao julgado pelo Supremo Tribunal Federal evidencia-se a necessidade de redimensionar a proteção legal direcionada às partes descartadas ou desprezadas do corpo humano. Assim, na ausência de uma firma tutela jurídica, a tendência é de que se aumente a pressão para as pessoas sejam compelidas, ou ao menos estimuladas a dispor de partes regeneráveis dos próprios corpos (SHREIBER, 2013, P. 41).

Já o segundo caso emblemático possui um pano de fundo com maiores peculiaridades, pois todo o imbróglio relaciona-se com o sequestro de um garoto chamado Pedrinho, em Brasília/DF, quando este era recém-nascido, ainda no hospital. Somente muitos anos após a data da subtração da criança é que foi possível confirmar que a autora do crime foi Vilma Martins Costa, a qual alegava ser mãe de Pedrinho.

O "quebra-cabeças" do caso foi se formando quando descobriu-se que a acusada teria realizado um procedimento de esterilização pouco antes do nascimento de outra filha sua, chamada Roberta Jamily Martins Borges, a qual, por coincidência possuía registro de nascimento na mesma data em que havia sido reportado um sequestro de uma recém nascida na mesma cidade e nas mesmas circunstâncias do desaparecimento de Pedrinho. Com tal suspeita levantada após as investigações policiais, o exame de DNA mostrava-se como meio fundamental para dirimir as suspeitas dos crimes. Ocorreu que Roberta, uma das filhas de Vilma, não quis disponibilizar material genético para a realização do exame.

Nesse momento é que uma pequena circunstância pessoal de Roberta chama a atenção do Delegado que presidia as investigações. Ao prestar depoimento na Polícia Civil, Roberta, que era fumante, descartou uma "bituca" de cigarro no lixo daquele distrito policial. Sabendo que a saliva continha material genético hábil para a realização de exame de perfil genético, o delegado determinou o envio daquela pequena amostra para a realização do exame de DNA. O resultado do exame confirmou a suspeita de que Vilma não era a mãe biológica de Roberta e mostrou que 
Francisca Maria era sua verdadeira mãe. Durante a fase judicial, a prova foi aceita e considerada lícita, uma vez que o resto de cigarro foi descartado e não houve intervenção corporal em Roberta. O magistrado entendeu que havia um interesse público pela solução do caso midiático e que a garantia da persecução penal estaria em um patamar superior em relação ao interesse individual e de privacidade de Roberta. Obviamente, considerada a expertise do delegado de polícia, a conduta de colher o material do lixo foi considerada genial e dentro da lei.

Tal informação foi considerada fundamental para que as investigações a respeito do caso de Pedrinho fossem ainda mais intensas. Assim, prosseguiu-se a marcha processual, oportunidade em que fora realizado exame de DNA no então menor Pedro Rosalino Braule Pinto ("Pedrinho"), o qual comprovou que este era, na verdade, filho de Jayro Tapajós Braule Pinto e Maria Auxiliadora Rosalino Braule Pinto, os quais tinham reportado o desaparecimento do recém-nascido no dia 21 de janeiro de 1986.

Desta forma, considerando o resultado positivo do exame de DNA realizado na vítima, bem como levando-se em conta as demais provas colhidas durante a investigação ${ }^{13}$, Vilma Martins Costa foi condenada por incorrer nas penas dos artigos 242 e 249, ambos do Código Penal.

\section{O CONFLITO DE PRINCÍPIOS E O FAIRPLAY PROCESSUAL}

Vencidas as questões introdutórias a respeito da teoria dos jogos, bem como analisados os peculiares casos práticos da jurisprudência nacional, o aprofundamento da discussão mostra-se necessário. Ainda que os julgados demonstrem situações muito distintas, destaca-se que a resolução do conflito de deu em razão do critério da

\footnotetext{
13 “O laudo pericial de exame de DNA de fls. 1933 usque 1935, demonstra que o menor Pedro Rosalino Braule Pinto (Pedrinho) é filho genético de Jayro Tapajós Braule Pinto e Maria Auxiliadora Rosalino Braule Pinto, sendo esta a pessoa da parturiente que tivera o filho referenciado subtraído pela acusada no interior do leito hospitalar da Casa de Saúde Santa Lúcia em Brasília no dia 21 de janeiro de 1986, terça-feira, por volta das 13 horas e trinta minutos. Ao longo da marca processual a douta defesa não nega peremptoriamente a credibilidade da referida perícia. Portanto, restou satisfatoriamente provado que o menor realmente se trata da criança subtraída na data e local constantes da tese acusatória posta em juízo. Embora a acusada negue ter estado no hospital e de lá subtraído a criança as provas carreadas aos autos demonstram exatamente o contrário além de ser reconhecida por mais de uma testemunha pessoalmente e através de "retrato falado" fotografia, de imagens televisivas." GOIÁS, Tribunal de Justiça do Estado de Goiás. $8^{\text {a }}$ Vara Criminal de Goiânia/GO. Ação Penal n. 299/2003. Protocolo n. 200300578312. Dje 24/08/2003.
} 
ponderação de princípios, no caso, entre o princípio do interesse público da persecução penal e o direito à intimidade, como uma especificidade do direito da personalidade.

Obviamente, em situações de conflito entre princípios e regras, fundamental é a referência clássica a Robert Alexy (2011), o qual entende que as colisões entre princípios devem ser dirimidas de forma diversa em relação ao conflito de normas ${ }^{14}$, sendo que se dois ou mais princípios colidem, um deles terá que ceder. Ou seja, isso não significa que o princípio cedente deva ser considerado inválido, bem como não deverá ser introduzida uma cláusula de exceção. O que ocorre é que um dos princípios invocados tem precedência em face do outro em determinadas condições do caso concreto. Em outras palavras, a precedência de um determinado princípio em um caso não pode ser alegada em circunstâncias diversas. Em síntese, os conflitos entre regras ocorrem na dimensão da sua validade, já as colisões entre princípios correm na dimensão do peso da situação posta (ALEXY, 2011, p. 93-94). Os princípios são deveres prima facie e as normas têm caráter definitivo.

Ocorre que o uso da ponderação na jurisprudência brasileira não está alinhado ao pensamento de Alexy. Objetivamente, as decisões que fizeram uso da ponderação, utilizaram o princípio da proporcionalidade, mas com um caráter distinto, aplicando a ponderação de forma superficial, somente conferindo o peso e dimensão aos princípios contrapostos e privilegiando o bem-estar social. Assim, considerando que as decisões são dotadas de autoridade, o magistrado acaba por "dizer o direito" não como um fato natural, mas como uma construção artificial para cumprir um anseio popular.

Como consequência lógica, aplicando-se o critério da ponderação de princípios como forma de resolução de conflitos e validando a sobreposição da garantia da persecução (mascarado como interesse público) sobre os demais princípios da personalidade e dos direitos individuais, obtêm-se uma flagrante violação ao fair-play (jogo limpo) processual penal. A notória tendência de atribuir menor peso às garantias individuais é alarmante, o que torna o jogo processual ainda mais desbalanceado. Quanto ao uso desmedido do princípio da proporcionalidade, Marco Antônio de Barros (2008, p. 20) afirma que há uma “cilada" na supremacia do

\footnotetext{
14 "Um conflito entre regras somente pode ser solucionado se se introduz, em uma das regras, uma cláusula de exceção que elimine o conflito, ou se pelo menos uma das regras for declarada inválida." (ALEXY, 2011, p. 92)
} 
interesse público dentro do processo penal. Assim, só seria aceitável a ponderação dos princípios de cunho individual e pessoal se realizado um juízo amplo de adequação, necessidade e estrita proporcionalidade no caso concreto. Ou seja, o que se critica é o uso desmedido da ponderação a ponto de tornar ineficaz o princípio da não autoincriminação.

Ao colocar o interesse público como preponderante na relação processual escancara-se a noção de que o sistema dito "misto" é falaciosa, pois é eminentemente (neo)inquisitorial ${ }^{15}$. Aliás, é argumento recorrente no âmbito processual de que os direitos individuais devem ceder frente à supremacia do interesse público. Como bem pontua Aury Lopes Jr., essa manipulação discursiva resulta em um maniqueísmo grosseiro para que se legitime o abuso de poder estatal. De forma objetiva, pode-se afirmar sem qualquer receio que o princípio que primeiro impera no processo penal é o da proteção dos inocentes. (LOPES, JR., 2018, p. 34-35).

Assim, a sobreposição do interesse público em detrimento das garantias individuais resulta em um inevitável desequilíbrio entre os jogadores, o que torna o jogo previsível, com a eminente condenação do réu. Utilizando-se que uma comparação muito adequada, Alexandre Morais da Rosa equipara o desequilíbrio do jogo processual ao doping esportivo, uma vez que a trapaça se torna um ingrediente necessário para garantir o "êxito" punitivista e para tornar os jogadores, através dos meios de comunicação, estrela do grande espetáculo midiático, sejam eles juízes, promotores, advogados e etc. (ROSA, 2017, 361-362).

Ainda que óbvio, parece ser necessário que se reafirme que o Estado não pode praticar ilegalidades para potencializar inescrupulosamente os elementos probatórios que lhes são mais favoráveis, principalmente quando este ocupa a posição com o maior aparato estrutural para o encarar o jogo do processo criminal. Objetivamente, doping é a materialização do jogo sujo, o qual, no âmbito esportivo é reprimido pelos comitês olímpicos e pelas agências antidoping. Tais agências buscam prevenir e reprimir as trapaças para garantir o fair play, de forma a proteger os atletas e o jogo em si (ROSA, 2017, p.363). Da mesma forma, utilizando-se de paralelismo, os princípios constitucionais do devido processo legal, ampla defesa e contraditório

\footnotetext{
15 “É lugar-comum na doutrina processual penal a classificação de 'sistema misto', com a afirmação de que os sistemas modelos históricos sem correspondência com os atuais. Ademais, a divisão do processo penal em duas fases (pré-processual e processual propriamente dita) possibilitaria o predomínio, em geral, da forma inquisitiva na fase preparatória e acusatória na fase processual, desenhando assim o caráter 'misto' (...) Nós preferimos fugir da maquiagem conceitual, para afirmar que o modelo brasileiro é (neo)inquisitório, para não induzir ninguém a erro. (LOPES JR., 2015, p. 151-152)
} 
(Art. 5, incisos LIV e LV, da Constituição da República), dignidade da pessoa humana (Art. $1^{\circ}$, inciso III, da Constituição da República), bem como a teoria das nulidades no âmbito infraconstitucional (no caso dos artigos 563 e seguintes do Código de Processo Penal) servem como fiscais das trapaças do jogo processual.

Assim, o antidoping dentro do jogo processual penal vincula-se às táticas dos jogadores, ou seja, a escolha de utilização de uma determinada prova, direito ao silêncio, formulação de perguntas em uma determinada linha de pensamento, por exemplo. Agora, tratando-se que uma ação penal movida pelo Ministério Público, não é aceitável o autodoping, como por exemplo a exclusão de prova fundamental à tese defensiva, a manipulação da investigação policial, a utilização de perguntas sugestionáveis e intencionalmente em favor do Estado, utilizando-se de argumentos para ganhar a torcida midiática, como ocorreu nos casos supracitados, onde o interesse midiático mascarado como "interesse público" foi preponderante. Relembrese que em ambos os casos é clara a manifestação negativa quanto à colaboração com materiais genéticos, seja qual fosse o grau de intervenção, os quais somente foram legitimados por serem considerados "descartáveis". Ou seja, o doping manipula o processo penal, pois ao inserir material ou método em desconformidade com os preceitos constitucionais, a condenação dopada não reflete o resultado justo (ROSA, 2017, p. 363-646).

Cabe destacar que assim como alguns atletas ainda buscam formas de burlar o controle antidoping, a prova dopada pode ser equivocadamente aceita através de um exercício falacioso de identidade de processos civis e criminais ${ }^{16}$. Tal possibilidade pode ser facilmente observada na utilização de provas emprestadas ${ }^{17}$, sob o argumento civilista de que há um dever de cooperação entre as partes para que se obtenha uma decisão justa ${ }^{18}$. Há aqui uma forçosa ideia de que há uma teoria geral do

\footnotetext{
16 "Não é porque o processo civil regulamente de um modo que se deve buscar ler o processo penal conforme o processo civil, justamente porque são pensados em lógicas diversas, sob pena de ocorrer parasitismo. (ROSA, 2017, p. 366)

17 "A prova emprestada, a saber, a importação de meio probatório não produzido nos autos em que será valorada, terá sempre o estatuto da prova documental, mesmo que se importem depoimentos, cuja reprodução seja impossível, tendo como pressuposto que as partes sem idênticas. (...) A candura como se faz o compartilhamento probatório merece maior reflexão. Surgindo hipótese de envolvimento de terceiros, a investigação deve ser promovida. Não se trata de prova pronta "como se" tivesse sido produzida em face do investigado. Por isso, pode servir, no máximo, como indício de investigação, instaurando-se o contraditório. Deve ser verificada a boa-fé, a ausência de barriga de aluguel, mesmo no encontro fortuito. Pensar o contrário é excluir o acusado da produção probatória e violar a regra do devido processo legal." (ROSA, 2017, p.723-724).

18“"Art. $6^{\circ}$ Todos os sujeitos do processo devem cooperar entre si para que se obtenha, em tempo razoável, decisão de mérito justa e efetiva.”
} 
processo plenamente aplicável ao processo penal, a qual justificaria um maior diálogo e entre os ramos. Nesse sentido, feliz é o questionamento feito por Aury Lopes Jr. a respeito das peculiaridades do processo penal: “Quando Cinderela terá suas próprias roupas?"19. Ao responder o questionamento, o autor salienta que não se trada de uma lide do ter, mas sim da liberdade. No lugar do bem material, pensa-se na liberdade, de quem está na iminência de perder (LOPES JR. 2015, p. 71).

Aliás, ainda que não seja o objeto principal da presente reflexão, a liberdade, ou melhor, a limitação da liberdade dentro do jogo processual também arca com as imposições de cunho inquisitorial. A motivação das decisões, sejam elas de mérito ou incidentais quanto à liberdade do jogador, são pautadas na ideia do in dubio pro hell, ou seja, na dúvida, o réu é mandado ao inferno da condenação, como afirma Salah Khaled Jr (ROSA; KHALED JR., 2014). Em outras palavras, trata-se de uma manipulação de preceitos para que a presunção de inocência deixe de ser encarada como princípio norteador, pois parte da ideia de que todas as acusações feita ao acusado possuem são presumidamente verdadeiras e a sua confirmação deve ser atestada a qualquer custo, para satisfazer o anseio punitivista estatal.

Objetivamente, e traçando um paralelo entre o mundo esportivo, a utilização de regras e princípios estranhos ao processo muito se assemelha à imposição de regras de jogo em esportes distintos. Em termos práticos, o jogo não se desenvolve e o resultado é previsível.

\section{CONCLUSÃO}

É irrefutável que as consequências do alto desenvolvimento tecnológico afetariam a forma como o direito, em especial o direito penal, passaria a enfrentar as múltiplas possibilidades relativas ao exame de material genético e sua utilização como meio de prova.

Conforme o exposto, os célebres casos da jurisprudência brasileira firmaram o entendimento de que o exame de DNA proveniente de tecido humano deve ser classificado como meio de prova não invasiva, pois não necessita de uma intervenção

\footnotetext{
19 "Todo um erro de pensar, que podem ser transmitidas e aplicadas no processo penal as categorias do processo civil, como se fossem a roupas da irmã mais velha, cujas mangas se dobram, para caber na irmã preterida. É a velha falta de respeito, a que se referia Goldschmidt, às categorias jurídicas próprias do processo penal." (LOPES JR. 2015, p.70)
} 
direta no corpo do indivíduo. Ocorre que mesmo não sendo uma forma invasiva, a manifestação a respeito de sua disposição não poderia ser desprezada, em razão do princípio do nemo tenetur se detegere. De fato, não há uma imposição para que o indivíduo colabora com a investigação tendo que se submeter a uma coleta de sangue, mas há uma mácula ao seu direito de intimidade no momento em que o Estado utilizase de tecidos renováveis e descartáveis como meio de prova mesmo com expressa manifestação contrária da parte.

Diante de um conflito entre os princípios individuais e suposto interesse público da persecução criminal, o segundo é utilizado como preponderante e desnivela ainda mais o jogo processual, o que torna o princípio da não autoincriminação inócuo, pois mesmo que não queria, o réu é prejudicado em razão da disposição de partes de seu corpo. Assim, o fair play processual deixa de existir e todas as jogadas e seus respectivos resultados se tornar previsíveis, basta que o réu aguarde a condenação.

Os reflexos dessa sobreposição inadequada de princípios aliada ao autodoping do órgão acusador reforçam ainda mais a crítica feita ao sistema, uma vez que passa a ter um caráter predominantemente inquisitorial, ou como alguns autores classificam: neoinquisitorial. Resta claro que aplicar a teoria da ponderação não resolve o problema, uma vez que a imposição do direito não se dá de maneira natural, mas como uma forma de satisfazer um anseio punitivista.

Portanto, conclui-se que os direitos individuais estão enfrentando um jogo duro, pois o plantel do adversário tem mais recursos e toda a torcida a seu favor, a derrota é eminente e inevitável.

\section{REFERÊNCIAS BIBLIOGRÁFICAS}

ALEXY, R. Teoria dos Direitos Fundamentais. Traduzido por Virgílio Afonso da Silva. Malheiros: São Paulo, 2011.

BARROS, Marco Antônio de; PISCINO, Marcos Rafael Pereira. DNA e sua utilização como Prova no Processo Penal. Universidade Presbiteriana Mackenzie. 2008. em: <http://www.mackenzie.br/fileadmin/Graduacao/FDir/Artigos_2008/Marco_Antonio_ de_Barros_2.pdf. 
BRASIL. Constituição (1988). Constituição da República Federativa do Brasil. Brasília, Senado, DF:1988.

BRASIL. Código de Processo Civil (2015). Disponível em < http://www.planalto.gov.br/ccivil_03/_ato2015-2018/2015/lei/113105.htm > Acessado em 08 de agosto de 2019.

BRASIL. Código de Processo Penal (1941). Disponível em <http://www.planalto.gov.br/ccivil_03/decreto-lei/del3689compilado.htm> Acessado em 08 de agosto de 2019.

BRASIL. Decreto N. 678 de 6 de novembro de 1992. Institui a Convenção Americana sobre Direitos Humanos. Disponível em:< http://www.planalto.gov.br/ccivil_03/decreto/1990-1994/anexo/and678-92.pdf >. Acesso em: 30 julho de 2019.

BRASIL. Decreto N.592 de 6 de julho de 1992. Institui o Pacto Internacional sobre Direitos Civis e Políticos. Disponível em:< http://www.planalto.gov.br/ccivil_03/decreto/1990-1994/D0592.htm>. Acesso em 27 de julho de 2019;

BRASIL. Supremo Tribunal Federal. Tribunal Pleno. Diário Oficial da União. Reclamação n. 2.040-1. Distrito Federal. 21 fev. 2002. Disponível em: <http://www.sbdp.org.br/arquivos/material/24_Recl\%202040.pdf>. Acesso em: 08 ago.2019.

CASTRO, C. R. A. Prova Científica: Exame Pericial do DNA. Rio de Janeiro: Lumen Juris, 2007.

GIACOMOLLI, Nereu José. Valor da prova no âmbito da cooperação jurídica internacional em matéria criminal. In PRADO, Geraldo; GIACOMOLLI, Nereu José et al (orgs). Prova Penal: Estado Democrático de Direito. Florianópolis: Empório do Direito, 2015.

GOIÁS, Tribunal de Justiça do Estado de Goiás. $8^{a}$ Vara Criminal. Autos de Ação Penal n. 299/2003.

HUIZINGA, Johan. Homo ludens. Trad. João Paulo Monteiro. São Paulo: Perspectiva, 2008;

LOPES JR., Aury. Direito processual penal. 15 ed. São Paulo: Saraiva Educação, 2018;

LOPES JR., Aury. Fundamentos do processo penal: introdução crítica. $1^{a}$ ed. São Paulo: Saraiva Educação, 2015.

MIRANDA, Francisco Cavalcanti Pontes de. Tratado de direito privado. Campinas, Bookseller, 2000, t. III, pp. 457-458. 
PACHECO, Carla Ferreira de Souza. A produção de provas com material genético descartado. Revista Saber Digital.v. 9, n. 2, p. 20-33, 2016. Disponível em <revistas.faa.edu.br/index.php/SaberDigital/article/download/205/169/> Acesso em 08 de agosto de 2019.

ROBLES, Gregório. La Justicia em los juegos. Madrir: Trotta, 2010.

ROSA, Alexandre Morais da. Guia compacto do processo penal conforme a teoria dos jogos. 2 ed., rev. e ampl. Rio de Janeiro: Lumen Juris, 2014.

ROSA, Alexandre Morais da. Guia do processo penal conforme a teoria dos jogos. $4^{\mathrm{a}}$ ed., rev. e ampl. Florianópolis: Empório do Direito, 2017.

ROSA, Alexandre Morais da; KHALED JÚNIOR, Salah H. In dubio pro hell: profanando o sistema penal. Rio de Janeiro: Lumen Juris, 2014.

SCHREIBER, Anderson. Direitos da Personalidade. 2.ed. São Paulo: Atlas, 2013.

WAMBIER, Luiz Rodrigues; TALAMINI, Eduardo. Teoria geral do processo e processo de conhecimento. 13 ed. São Paulo: Revista dos Tribunais: 2013. 